\title{
Terms of Sensory Perception in English and Vietnamese Metaphorical Expressions of Love
}

\author{
Ho Trinh Quynh Thu ${ }^{1}$, Phan Van Hoa ${ }^{2}$ \\ ${ }^{1}$ Postgraduate Training, the University of Danang, Da Nang, Vietnam \\ ${ }^{2}$ School of International Education, the University of Danang, Da Nang, Vietnam
}

Email address:

hotrinhquynhthu@yahoo.com (H. T. Q. Thu), hoauni@gmail.com (P. V. Hoa)

To cite this article:

Ho Trinh Quynh Thu, Phan Van Hoa. Terms of Sensory Perception in English and Vietnamese Metaphorical Expressions of Love. International Journal of Language and Linguistics. Vol. 4, No. 2, 2016, pp. 47-56. doi: 10.11648/j.ij11.20160402.11

\begin{abstract}
The terms of sensory perception metaphorically used to express love are rather diversified in English and Vietnamese poetry. All five senses are exploited for different purposes of love expression. They contribute to the variety in love and help it easier to understand. In the light of the conceptual metaphor theory, fifteen source domains for love are found underlying 1190 sensory perception expressions (549 English and 641 Vietnamese). All the conceptual metaphors and many of the metaphorical expressions are the same in the two languages. These resemblances may be explained by the universality of metaphor and of the conceptual organization of sensory perception in human brain. However, coming from two different cultures, these terms are not completely similar between English and Vietnamese.
\end{abstract}

Keywords: Metaphor, Conceptual Metaphor, Metaphorical Expressions, Love, Sensory Perception Terms

\section{Introduction}

It is said to be very difficult to shed light on love clearly and exactly. There is not any specific definition of love; however, it is found rather multiform in language. Hendrick and Hendrick argue "love takes different forms for different people in different situations" [27]. In fact, its diversity is majorly results of using metaphors that, according to the conceptual metaphor theory raised by Lakoff and Johnson [19], delineate a more abstract concept in terms of a typically more concrete concept based on our experience.

Drawing on this theory, more and more researches of metaphors have been done in many linguistic fields. For metaphors of love, they have been much examined in monolingual data (viz. English, Chinese, Hungarian, Vietnamese...) or bilingual (usually English versus such another language as Chinese, Persian or Vietnamese) in different registers (e.g., psychology, literature in general, poetry, song lyrics...). Many researches also prove the universality and variation of the conceptual metaphors of love in different languages (see Kovecses, 2000; Tran Thi Thanh Thao, 2011; Ho Trinh Quynh Thu, 2011; Mashak, 2012; Zitu Lv, 2012; Le Thi My Trinh, 2013).

Interestingly, English sensory languages in love metaphorical expressions were examined by Tessari [31].
The data for her investigation are the expressions with the word "love" in general sense (consisting of family love, sexual love, friendship love, religious love and love of things). However, the study hardly provides any specific data or samples to illustrate the existence of sensory language for love except a conclusion of PERSON, FOOD and HEAT domains for love conceptualization.

Different from Tessari's study, our research will focus on sensory perception expressions metaphorically used for romantic love (with or without this word) - the love shared by a couple when they fall in love - in English and Vietnamese poetry, which has not been done in the history yet. Therefore, we will answer the following questions:

(1) How can romantic love (henceforward love) be expressed in terms of sensory perception in the light of the conceptual metaphor theory?

(2) Are there any universalities or variations in English and Vietnamese metaphorical expressions of love via sensory perception terms?

Before solving these two problems, we will have a brief review of the conceptual metaphor theory, the metaphors of love which will be presented in the second part. A distinction between metaphor and metonymy and the relationship between metaphor and culture will also be provided in this part. The concepts related to the subject will also be 
discussed in section three. Our study results will be displayed in the fifth section after we introduce the research methodology.

\section{Metaphor}

\subsection{Conceptual Metaphor Theory}

Metaphor viewed in the light of cognitive science is called cognitive or conceptual metaphor. Its working mechanism is a cross-domain mapping which is defined as "a fixed set of ontological correspondences between entities in a source domain and entities in a target domain" [18]. The conceptual mappings of metaphors are tightly structured, asymmetric, unidirectional, partial based on daily experiences and have a definite structure: TARGET-DOMAIN IS/AS SOURCEDOMAIN [18] (see figure 1).

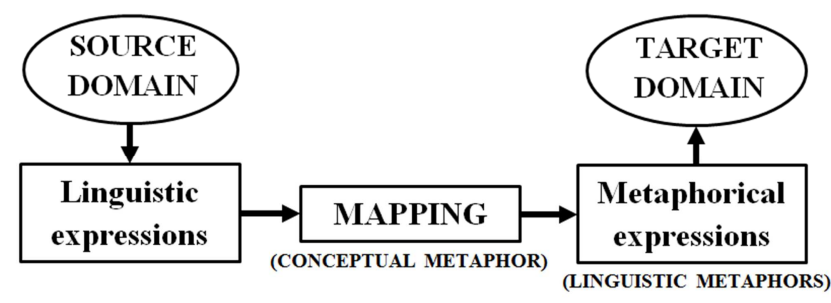

Figure 1. The conceptual mapping.

To describe a love relationship, for example, one uses: Our relationship has hit a dead-end street. Here love is being conceptualized as a journey, or the mapping LOVE IS A JOURNEY is structured. In this mapping, "LOVE IS A JOURNEY" is the name of the mapping or conceptual metaphor; LOVE is the target domain, JOURNEY is the source domain; such sentence as Our relationship has hit a dead-end street is individual linguistic metaphor or metaphorical expression that is understood via that set of the correspondences between the source and the target domains. In other words, linguistic metaphors (or metaphorical expressions) are what expressed by language; and conceptual metaphor refers to a mental representation describing how two words or expressions from apparently different domains may be associated at an underlying cognitive level.

\subsection{Conceptual Metaphors of Love}

Kovecses [14] holds our language (English) uses metaphors that are derived from our experience to relate emotion (including love) by virtue of its lack of vocabulary. In his research process, he finds out twenty four typical conceptual metaphors of love in English, including those raised by Lakoff and Johnson [19]. However, there are some overlaps between them, which may lead to an unreal result in statistic processes. Hence, to prevent such a result from metaphoric expression overlapping, we will facilitate our study by grouping those that have similar characteristics together. The list now includes sixteen source domains for love (namely, CONTAINER, JOURNEY, FORCE,
MADNESS, MAGIC, WAR/SPORT, RAPTURE, NUTRIENT, UNITY, FIRE, OBJECT, OPPONENT, CAPTIVE ANIMAL, DISEASE, LIVING ORGANISM, SOCIAL SUPERIOR).

\subsection{Metaphor and Metonymy}

Metaphor and metonymy are closely related. They are conceptual in nature (i.e., structured in thoughts), conventionalized (i.e., automatic, unconscious and effortless), and interpreted via mapping processes [18]. However, it is necessary to distinguish metaphor from metonymy. Metonymy "involves only one conceptual domain. A metonymic mapping occurs within a single domain" while metaphor is defined as a cross-domain mapping [18]

\subsection{Metaphor and Culture}

According to Lakoff and Johnson [19], metaphor is universal. However, Lakoff [18] supposes "metaphorical mappings vary in universality; some seem to be universal, others are widespread, and some seem to be culture specific". Therefore, metaphor may also be seen as a product of culture and under its influence. Kovecses [15] argues "metaphors are based on cultural considerations and cognitive processes". Analogously, Gibbs [10] considers culture as an important factor from which our thoughts cannot be separated. It may accordingly be said that metaphor and culture are not separable. Culture creates the diversity of metaphors in each language and different languages

\section{Senses and Sensory Perception}

Sensory perception is the understanding gained by or based on stimulation of the senses such as sight, taste, touch, hearing and smell. It occurs in living things that are capable of performing neurophysiological processing of the stimuli in their environment via the senses. The sensory modalities (i.e. the way of sensing, including visual, auditory, tactile, olfactory, gustatory, kinesthetic, etc. [13]), on Plessner's view, are essentially interrelated with these mental and bodily phenomena, and only this integrated whole gives us genuine sensory perception [3]. Accordingly, sensory perception is a both mental and physical process.

\section{Methodology}

\subsection{Data Collection}

The data for investigation are mainly collected from fourteen poetry books of 400 English love poems and 400 Vietnamese ones. They are possibly regarded as equivalent in composing time, including before $20^{\text {th }}$ century, in the $20^{\text {th }}$ and early $21^{\text {st }}$ centuries.

\subsection{Identification of Metaphorical Expressions}

Identification of linguistic metaphors is an important step 
in the procedure for studying metaphors because to know the existence of conceptual metaphors in a discourse, we need to know which linguistic metaphors point to them [16]. It helps ensure the reliability and validity of the study results. In this study, we will apply the approaches to metaphor identification raised by Pragglejaz Group [25] including four steps: (1) Read the entire text-discourse to generally understand the meaning. Next, (2) determine the lexical units in the text-discourse. Then (3) take into account what comes before and after the lexical unit, determine if it has a more basic contemporary meaning in other contexts than the one in the given context. If yes, decide whether the contextual meaning contrasts with the basic meaning but can be understood in comparison with it. If yes, (4) mark the lexical unit as metaphorical.

\subsection{Research Methodology}

To carry out this study, we employ descriptive, statistical and comparative methods. They helps us analyse, understand and synthesize love metaphorical expressions, discover the cultural features that effect on expressing love metaphors and determine the similarities and differences of love metaphorical expressions between English and Vietnamese.

\section{Findings and Discussions}

Ten among sixteen typical source domains for love presented in 2.2 are discovered underlying 1190 expressions (549 English and 641 Vietnamese) of five senses (vision, audition, gustation, olfaction and tactition). They are OBJECT, NUTRIENT, CONTAINER, UNITY, JOURNEY, FIRE, LIVING ORGANISM, DISEASE, RAPTURE and OPPONENT. Besides, there are also five others (namely BLINDNESS, PLANT, MUSIC, LIFE and SUN/MOON/STARS). They are all displayed in the tables 1 and 2 below, in which the abbreviations are understood as follows: $\mathrm{Vi} .=$ visual perception terms $(\mathrm{pts})$, Tac. $=$ tactile $\mathrm{pts}$, $\mathrm{Au} .=$ auditory pts, Gus. $=$ gustatory pts and Ol. = olfactory pts.

Table 1. The conceptual metaphors of love underlying English sensory perception terms.

\begin{tabular}{llll|ll}
\hline Conceptual metaphors & Vi. & Tac. & Au. & Gus. & Ol. \\
\hline OBJECT & 117 & 24 & & & 2 \\
CONTAINER & 49 & & 1 & & \\
UNITY & 41 & & & & \\
BLINDNESS & 40 & 3 & 3 & 2 & 1 \\
JOURNEY & 32 & & & & \\
SUN/STAR/MOON & 31 & 3 & & & \\
FIRE & 24 & 20 & & 1 & \\
LIVING ORGANISM & 22 & 5 & & & \\
PLANT & 9 & & & & 2 \\
OPPONENT & 6 & 15 & 6 & 1 & \\
LIFE & 5 & & & & \\
RAPTURE & 2 & 1 & 1 & 1 & \\
DISEASE & & 14 & & & \\
MUSIC & & & 8 & & \\
NUTRIENT & 378 & 85 & 19 & 60 & 7 \\
TOTAL & &
\end{tabular}

Table 2. The conceptual metaphors of love underlying Vietnamese sensory perception terms.

\begin{tabular}{llllll}
\hline conceptual metaphors & Vi. & Tac. & Au. & Gus. & Ol. \\
\hline OBJECT & 99 & 25 & 1 & & \\
JOURNEY & 68 & & & & \\
UNITY & 68 & & & & \\
CONTAINER & 50 & 1 & & & \\
PLANT & 49 & & & 2 & 24 \\
BLINDNESS & 37 & 1 & 2 & 1 & 2 \\
SUN/STAR/MOON & 28 & 12 & & & \\
FIRE & 11 & 41 & & & \\
OPPONENT & 9 & 24 & & 1 & \\
LIVING ORGANISM & 8 & & 6 & & \\
RAPTURE & 4 & & 12 & & \\
LIFE & 2 & 1 & 1 & & \\
DISEASE & & 21 & & & \\
MUSIC & & & 4 & & 28 \\
NUTRIENT & & & & 24 & 28 \\
TOTAL & 433 & 126 & 26 & 28 & 28 \\
\hline
\end{tabular}

\subsection{Visual Perception Terms in Metaphorical Expressions of Love}

Visual perception is the ability to interpret the surrounding environment by processing information through eyes. The visual sense is referenced by talking about light and dark, shades and hues, visible shape and appearance [34]. Most of these visual imageries are able to be found in English love expressions.

(1) Such is the beauty of love - always instilled, never taught. (Jason Sturner)

(2) My love for you is vaster than the ocean (Nicolas Gordon)

(3) Promise me that our love will never fade or disappear (Bobette Bryan)

Love in the examples above is conceptualized as an object that has its appearance and described via poets' visual perception. The expressions "beauty" (of love), "vaster", "fade", "disappear" make it more concrete. Such similar terms are also present in Vietnamese.

(4) Ái tình đẹp tợ chúng em đây! (Love is as beautiful as we are) (Xuân Diệu)

(5) Cao rộng tình ta rục ráng chiều (Our high and wide love, radiant evening clouds) (Xuân Diệu)

(6) Tim em $u$ ám màu thương nhớ. (Her heart is dark for missing) (Nguyễn Thanh Tùng)

Obviously, the information of love appearances is received by eyes and reflected through the adjectives "đẹp" (beautiful), "rực" (radiant), "u ám" (dark), "cao rộng" (high and wide) and the noun "màu" (colour). These expressions make love more concrete and visible. Besides, the concretization of love is also manifested in visible specific shapes as follows:

(7) No one can tell why one of all the rest Makes our flower open to the sun. (Nicholas Gordon)

(8) My love, her mistress, is a gracious moon (Shakespeare) 
(9) Nàng rằng: "Khoảng vắng đêm trường, Vì hoa nên phải đánh đường tìm hoa..."

(She said: "Through a deserted space and a long night, I have to try to seek the way to flower for flower) (Nguyễn Du)

(10) Ngục đời người không có mặt trời yêu. (There is no love sun in the jail of human life) (Xuân Diệu)

Love in the verses above is described in shapes of the mighty beautiful natural phenomena. They are flower, sun and moon. With these images, love becomes magnificent, treasured and important to human life.

Besides, the loved in the eyes of the persons in love are also always beautiful. Looking back on example (9), the image "hoa" (flower) may refer to love and may also be compared to the loved person even a male. (It may be a unique character in the Story of Kiều.) This image helps to confirm that the partner (irrespective of sex) in the love relationship is always charming in the eyes of each other. (S)he is also considered resplendent, precious, and especially necessary for living:

(11) You are my moon, my sun and stars My earth, my sky, my sea. (Nicholas Gordon)
Returning to the example (9) again, we can see that the visibility of love is expressible in terms of visual perception the Vietnamese verb "tìm" (seek); and a similarity is also found in English but it is "find":

(12) You cannot help but find a love (Nicolas Gordon)

Up to now, it may be said that love becomes more concrete and easier to interpret thanks to visual metaphorical expressions in both English and Vietnamese. It is vision that pictures and shows how beautiful and in what shapes love is. Besides, the concretization of love is also manifested through visual terms where love is considered as a living organism that has the organ of sight - eyes.

(13) Our love will always see us through (Bobette Bryan)

(14) Love's eye is not so true as all men's no. (Shakespeare)

(15) Và đôi trái tim tìm nhau, mãnh liệt!

(And the two hearts are looking for each other violently) (Xuân Diệu)

Obviously, love in the lines above is personified by the noun "eye", the verbs "see" in English and "tìm" (look for) in Vietnamese. These words are all used to talk about one's sight, and especially love's sight in the poems.

Table 3. Visual perception terms in English (E) and Vietnamese (V) metaphorical expressions (MEs) of love.

\begin{tabular}{|c|c|c|}
\hline Word class & ENGLISH MEs & VIETNAMESE MEs \\
\hline $\begin{array}{l}\text { Nouns (E: 187; V: } \\
\text { 261) }\end{array}$ & $\begin{array}{l}\text { ace, beauty, colour, halo, eyes, flower, look, moon, light, } \\
\text { lk, darkness, brightness, sea, depth, trace, seal, ring, height, } \\
\text { reness, emptiness, sun-shadow, house... }\end{array}$ & $\begin{array}{l}\text { ánh sáng, màu, vẻ đẹp, cá } \\
\text { tròn, vệt, chồi, thuyền, khôn } \\
\text { diệp, xích thằng, ngọn lửa, } \mathrm{d}\end{array}$ \\
\hline Verbs (E: 89; V: 65) & find, see, relume, glow, light, quench, look, seek, spy, fade... & $\begin{array}{l}\text { thây, ngó, tìm, gặp, kiếm, liếc mắt, ngắm, nhìn, gặp gỡ, nhận } \\
\text { ra... }\end{array}$ \\
\hline $\begin{array}{l}\text { Adjectives (E: 90; } \\
\text { V98) }\end{array}$ & $\begin{array}{l}\text { beautiful, elegant, blind, fair, glorious, lovely, pretty, newfound, } \\
\text { high, empty, spin, gross, black, pale, unseen, scarlet, gentle... }\end{array}$ & $\begin{array}{l}\text { rực rỡ, trắng xóa, tiêu điều, đẹp, lộng lẫy, lấp lánh, tươi, u ám, } \\
\text { đỏ, bạc phếch, thắm, xiêu xiêu, ngốn ngang, chênh vênh, vẹn } \\
\text { hình, xao xác, trĩu nặng, tròn, khuyết... }\end{array}$ \\
\hline Others (E: 12; V: 10) & brilliant colours, through eyes, in the shape of, in the circle... & mắt cười, nhuộm màu thần tiên, sắc màu rực rỡ, mắt thấy... \\
\hline
\end{tabular}

Looking back on the examples 1-15, we may conclude that English and Vietnamese visual terms metaphorically used for love are mainly in three of the four major word classes (namely verbs, nouns and adjectives), which is shown in table 3 .

\subsection{Tactile Perception Terms in Metaphorical Expressions of Love}

Tactile perception is the interpretation of information provided by skin sensations. The sense of touch is the ability to feel or be aware of something physical by touching it [28]. As a result, the verb touch may be mainly responsible for recognizing and communicating the information of tactile sense. It is also metaphorically applied to translate love in English and Vietnamese.

(16) Your warm and radiant light/ touched my soul (Bobette Bryan)

(17) ... không có tình yêu nào ta chạm vào trọn vẹn (...there is no love that we can touch completely) (Nguyễn Phong Việt)

In (16) love is personified and capable of touching. By contrast, the love in (17) is conceptualized as an object, a concrete thing that can be touched by the persons in this relationship. Touch is responsible for dealing with the data of texture, pressure, pain and temperature. Texture is treated as the physical feel of something (e.g. smooth, rough, soft, slimy...).

(18) Fair is my love, but not so fair as fickle; (...)

Softer than wax, and yet, as iron, rusty (Shakespeare)

By using the adjective "soft", Shakespeare conceptualizes love as an object. Soft expresses a pleasant and smooth feeling when touched [28]. As it is described to be soft, love seems to bring the ease and comfort to who owns it. Such perception also appears in Vietnamese (e.g. Tình yêu như mũi nhọn, êm ái và ngọt ngào - Du Tử Lê). More surprisingly and wonderfully, this sensory imagery - soft (mềm) is exploited to talk about the state of life, of revivification.

(19) Ai làm cho trái tim mềm ấm lại...?

(Who makes my heart soft and warm again...?) (Nguyễn Thị Thu Hương)

In this case, the heart image may be interpreted in two ways, (1) a metonymy where the heart stands for the woman and (2) a metaphor where the heart is regarded as her love. In 
such ways of understanding, we can learn that love here is considered bringing life to a human being, making the love in her heart revive via the metaphor LOVE AS LIFE. Besides, this conceptual metaphor is also manifested under the metaphorical expression "ấm” (warm) in this example. Warm is perceived due to the textile sense but it does not belong to texture. It is temperature perception, which is much employed in describing love.

(20) Love's fire heats water, water cools not love. (Shakespeare)

(21) There's a batch of romance now simmering in the heart- (...) the degree of love determines its heat. (Jason Sturner)

Love in these lines is interpreted as fire thanks to the terms of temperature perception "heat" and "cool". As being fire, love can make the heart of the person in love hot by its heat (see example 21). Love's fire can even heat water but, contrary to natural phenomena, water cannot make it go out (see example 20). The image of love's fire with temperature expressions is also popular in Vietnamese poems,

(22) Đầu mày cuối mắt càng nồng tấm yêu.

(The more he looks at her eyes, the hotter his love for her is) (Nguyễn Du)

(23) Đốm lửa tình duyên tắt nguội dần

(The extinguished love's fire cools down gradually)(Nguyễn Bính)

Clearly, love described in temperature terms "nồng" (very hot) and "nguội" (cool down) in these lines becomes more corporeal. The corporeality of love appears to be clearer with the expressions of pressure on the skin surface. They may be light, heavy (in English) or nặng, nhe (in Vietnamese):

(24) Is love so light, sweet boy, and may it be

That thou shouldst think it heavy unto thee? (Shakespeare)

(25) Bên tình, bên hiếu, bên nào nặng hơn?

(Love or piety, which is heavier?) (Nguyễn Du)

In addition to texture, temperature and pressure, pain is also referred to tactile perception. It is usually considered a negative feeling caused by disease, injury, or something that hurts the body. Besides physical feeling, it is also utilized to interpret unpleasant experiences of emotion, typically love.

(26) I know I must have hurt you, caused you pain. (Nicolas Gordon)

(27) Chắc có lẽ tim em tan vỡ Vì đang đau trong mối tình đầu

(Maybe my heart is broken Because of the pain of my first love) (Thanh Tùng)

(28) Bắt đầu của nỗi đau bao giờ cũng là những yêu thương

(Love is always the beginning of pain) (Nguyễn Phong Việt)

Evidently, negative sensations of love experience are chiefly expressed in terms of pain perception. They may be pain, agony, hurt, ache, aching... in English and nồi đau, đau, nhức, buốt... in Vietnamese.

In brief, so many tactile perception terms can be found in both English and Vietnamese love expressions (see table 4).
They are varied relying on the experiencer's state of mind. With these terms, love may be a satisfaction with enjoyable and pleasant experiences; but it also sometimes makes one or both of the individuals in the relationship fall in its dark side where there are unpleasantness, disappointment and even pains.

Table 4. Tactile perception terms in metaphorical expressions of love.

\begin{tabular}{|c|c|c|}
\hline Perception & English MEs & Vietnamese MEs \\
\hline Pressure & heavy, light, tender & nặng, nhẹ \\
\hline Texture & soft & mềm, êm ái \\
\hline Temperature & $\begin{array}{l}\text { freezing, temperate, hot, } \\
\text { cold, cool, cozy, numbing, } \\
\text { warm, ardour, heat, } \\
\text { warmth, chill... }\end{array}$ & $\begin{array}{l}\text { giá, lạnh, se se lạnh, mát, } \\
\text { nồng, nồng ấm, nóng, } \\
\text { nguội, rét, hơi ấm, sưởi ấm, } \\
\text { ủ âm... }\end{array}$ \\
\hline Pain & $\begin{array}{l}\text { tortured, pain, agony, ache, } \\
\text { sore, torture, hurt... }\end{array}$ & $\begin{array}{l}\text { buốt, nhức buốt, đau, xót } \\
\text { xa, nhói, tê tái, quặn đau, } \\
\text { nỗi đau... }\end{array}$ \\
\hline Others & touch, feel, feeling & chạm \\
\hline
\end{tabular}

\subsection{Gustatory Perception Terms in Metaphorical Expressions of Love}

Gustation is the sensation or act of tasting [21]. When talking about this sense, we cannot help mentioning to the word "taste". Taste helps us examine whether the flavour of something is good or not. Interestingly, human beings appear to enable to "taste" love; it is probably by virtue of its own "taste".

(29) When you soared into my life I tasted true happiness for the first time. (Bobette Bryan)

(30) Hương gây mùi nhớ, trà khan giọng tình!

(Fragrance makes him miss her and his tea tasteless) (Nguyễn Du)

Happiness is always accompanied by love. Ortiz-Millán [23] argues that it is hardly to talk about love separated from other feelings such as happiness, sadness and even hatred. The feeling happiness in (27) is obviously referred to love, which is brought by "you" when "soaring into my life". This happiness or just the love becomes much realer based on the expression of the verb "taste" via the LOVE AS A NUTRIENT metaphor.

Since it is conceptualized as a nutrient, love has its own taste. Excitingly and originally, the taste of love described by Nguyen $\mathrm{Du}$ in (30) lies in tea via the expression "trà khan giọng tình" (tea without love taste). In fact, Kim's cup of tea becomes tasteless owing to the absence of love, of his beloved - Kiều.

Although it may be perceived, the love taste in the two cases above has not been shown clearly yet, unlike the following instances:

(31) Life isn't easy, but I know without you There will be bitterness in all I do. (Nicolas Gordon)

(32) Bao giờ có được người yêu dấu! Chất chứa trong lòng vạn đắng cay.

(When could I have my beloved? It is always my bitters.) (Xuân Diệu) 
Horrible feelings in love may be received and translated in gustatory language. With bitterness and đắng cay, love in (31) and (32) is defined as some substance with a harsh and disagreeable taste that may make people resentful and unpleasant. It is one of five basic tastes, namely sweetness, sourness, saltiness, umami and bitterness, categorized into two types - appetite and aversion. Both types are able to be found in love metaphorical expressions in English and Vietnamese poetry. The aversive taste is typically shown in (31) and (32). The rest one is manifested in the following stanzas:

(33) Let us roll all our strength and all Our sweetness up into one ball (Andrew Marvell)

(34) Cũng từ ánh mắt Trao nhau ngọt ngào

(From our look, sweetness is offered to each other) (Trần Thị Lợi)

Love in (33) and (34) is conceptualized as a substance, also perhaps a nutrient containing sugar or honey, thus "sweet". Sweetness is universally known as a pleasurable experience. It is often used to talk about positive emotional feelings such as love and happiness. It is consequently said "the longing for sweets is really a yearning for love" [35].

(35) O slanderous world! Kate... sweeter than the kernels. (Shakespeare)

(36) Em trong anh tha thiết ngọt ngào

(I'm earnestly sweet in you) (Dương Thị Thu Vân)

As can be seen from (35) and (36), the person in love is also no less sweet than love. With the meaning of satisfying and pleasant, sweetness is used to convey the bliss the persons in love experience. They find their love, their beloved and even themselves sweet and lovely. Beside sweetness and bitterness, others tastes involving sourness, salty, tasteless, umami... are also present in metaphorical expressions of love, which are exhibited in table 5.

Table 5. Gustatory perception terms in English and Vietnamese metaphorical expressions of love.

\begin{tabular}{lll}
\hline Taste & English MEs & Vietnamese MEs \\
\hline \multirow{2}{*}{ Appetitive } & $\begin{array}{l}\text { sweetness, honey, sweet, } \\
\text { sweeting, sweetly, }\end{array}$ & $\begin{array}{l}\text { ngọt, ngọt ngào, ngọt lịm, } \\
\text { ngọt bùi, dịu ngọt, ngon, mặn } \\
\text { mà... } \\
\text { chua, đắng, lạt, đắng cay, vị } \\
\text { đắng }\end{array}$ \\
Aversive & bitterness, sour, bitter & chua ngọt, vị, giọng \\
\hline
\end{tabular}

In short, love seems more specific and substantial thanks to the terms of gustatory perception. It is also manifested in many distinctive tastes, which creates the diversity of love. Correspondingly, taste may be seen having an important part in expressing love. Maybe gustatory terms are ingredients that are indispensible in the metaphorical expressions of love.

\subsection{Olfactory Perception Terms in Metaphorical Expressions of Love}

Olfaction works based on olfactory receptors in nose. They are used to discover the presence of smell, distinguish an odour among different others of substances; and perhaps the odour of love is always perfume.

(37) The aroma of spring love swirls around us. (Jason Sturner)

(38) Hoa tình yêu chợt nở Hương tình yêu say say

(The love flower has just bloomed

The love scent is charming) (Đoàn Thị Lê)

In these instances, love may be thought of as a plant where the flowers bloom and spread their perfume. Furthermore, the smell may be perceived from the beloved:

(39) I'll smell thee on the tree. (Shakespeare)

(40) Má em mận chín ngỡ thu mùa

Hương bay ngào ngạt thơm ngào ngạt

(Your cheeks are as pink as autumn plums, their perfume pervades the air) (Nguyễn Thanh Tùng)

Also via the PLANT metaphor, love from (39) to (40) is understood in terms of olfactory perception drawing the loved persons. These objects of love are the products of a plant such as flowers and fruit. Accordingly, the persons in this love relationship can "smell" these perfumes pervade the air. Till now, we may draw a conclusion frankly that olfactory perception partly contributes to the enrichment of multi-flavoured love (see table 6)

Table 6. Olfactory perception terms in metaphorical expressions of love.

\begin{tabular}{|c|c|c|}
\hline Word class & English MEs & Vietnamese MEs \\
\hline Nouns & $\begin{array}{l}\text { aroma, perfume, } \\
\text { fragrance, smell }\end{array}$ & hương, mùi hương, mùi \\
\hline Verbs & Smell & \\
\hline Adjectives & delicate, fragrant & $\begin{array}{l}\text { ngào ngạt, ngát hương, thơm } \\
\text { ngát, nồng nàn, thơm, ngát }\end{array}$ \\
\hline
\end{tabular}

\subsection{Auditory Perception Terms in Metaphorical Expressions of Love}

Auditory perception is ability to perceive sounds through ears. However, Fell [8] argues "we don't necessarily hear what is there; we hear what we think is there". Hearing consequently appears not to lie at ears but lies at the human heart, which may be true in love.

(41) You are a song within my breast, your soft caress, love's melody (Bobette Bryan)

In these lines, love is conceptualized as music, but perhaps it is not received through ears. When mentioning a "song" or a "melody", we usually think of musical sounds. They are obviously terms of auditory perception used to describe love. Similar situations can also be found in Vietnamese.

(42) Và tiếng lòng anh gọi em

Như ru... như ru...

(And your heart calls me delusively...)(Lê Giang)

Unlike (41) where love is something that produces sounds, love in (42) is personified by "gọi" (call). The expressions "tiếng" (voice) and "gọi" belong to audition. They can only be received via auditory receptors. "Tiếng lòng" (inner voice) or the voice from the heart is just the voice of love; and thus, only the persons in love with each other can perceive this sound. Besides, there are some other terms of auditory perception metaphorically used for love in both English and 
Vietnamese, which are shown in the table 7 below.

Table 7. Auditory perception terms in metaphorical expressions of love.

\begin{tabular}{lll}
\hline $\begin{array}{l}\text { Word } \\
\text { class }\end{array}$ & English MEs & Vietnamese MEs \\
\hline Nouns & $\begin{array}{l}\text { tune, voice, song, } \\
\text { dissonance, music, sonata, } \\
\text { thunder, melody } \\
\text { hear, deafen, sing }\end{array}$ & $\begin{array}{l}\text { tiếng thì thầm, tiếng lòng, tiếng } \\
\text { nấc, ngũ âm, tiếng chuông gió } \\
\text { hót, nghe, gọi, reo, vang, rộn }\end{array}$ \\
Verbs & splattered, mute & $\begin{array}{l}\text { lặng ngắt, xôn xao, rộn rã, rộn } \\
\text { rang } \\
\text { nghe hay, nghe .... trong tai, } \\
\text { nghe xôn xao }\end{array}$ \\
\hline
\end{tabular}

In short, the auditory terms, along with the language of four other senses (vision, tactition, olfaction and gustation) make a relatively complete description of love. By the terms of sensory perception, we may contemplate a beautiful picture of love with the light colours, and concurrently experience the dull side of love drawn in dark colours. All of them create the diversity and tangibility of love in both English and Vietnamese.

\subsection{Similarities and Differences Between English and Vietnamese Sensory Perception Terms in Love Metaphorical Expressions}

Sensory perception terms are creatively used to express love in both English and Vietnamese poetry. In the process of analysis and discuss these expressions, we find many similarities and dissimilarities between English and Vietnamese sensory perception terms applied to describe love.

\subsubsection{Similarities}

Though in distinct cultures, the terms of sensory perception employed for love have many resemblances. All the five senses are detected in both English and Vietnamese metaphorical expressions of love. The visual perception terms are used the most among the others in both the languages. Their ratios are also nearly equal, 68.85 per cent in English and 67.55 per cent in Vietnamese. The overwhelming number of visual perception terms may be explained by a hypothesis of the preference for visual information where sight is supposed to be 'given more attention and better known than others' [30]. Feng and Lapata [9] also argue 'visual information may play a role in the human acquisition of word meaning'.

Table 8. The quantities of sensory perception terms in English and Vietnamese love metaphorical expressions.

\begin{tabular}{l|llll}
\hline \multirow{2}{*}{ Senses } & English & \multicolumn{3}{c}{ Vietnamese } \\
\cline { 2 - 5 } & Frequency & \% & Frequency & $\%$ \\
\hline Vision & 378 & 68.85 & 433 & 67.55 \\
Tactition & 85 & 15.48 & 126 & 19.66 \\
Gustation & 60 & 10.93 & 28 & 4.37 \\
Audition & 19 & 3.46 & 26 & 4.06 \\
Olfaction & 7 & 1.28 & 28 & 4.37 \\
\hline
\end{tabular}

Table 9. Word classes of English and Vietnamese sensory perception terms metaphorically used for love.

\begin{tabular}{lllll}
\hline \multirow{2}{*}{$\begin{array}{l}\text { Word } \\
\text { classes }\end{array}$} & English & \multicolumn{3}{c}{ Vietnamese } \\
\cline { 2 - 5 } & Number & $\mathbf{\%}$ & Number & \% \\
\hline Noun & 246 & 44.81 & 296 & 46.18 \\
Verb & 126 & 22.95 & 87 & 13.57 \\
Adjective & 161 & 29.33 & 245 & 38.22 \\
Others & 16 & 2.91 & 13 & 2.03 \\
\hline
\end{tabular}

Going right after vision is the sense of touch in both English and Vietnamese love metaphorical expressions with 15.48 and 19.66 per cent respectively (see our statistics in table 8). Perhaps it is a result of the desire of attachment and closeness in love relationship. Tactile perception is a physical direct contact with a high degree of reciprocity [29]; hence, 'to touch is to be touched' [26]. It requires little distance for which any person in love is always longing.

In addition, the word classes of sensory perception terms utilized to express love are mainly nouns, adjectives and verbs in both languages (see table 9). These linguistic items may be evidence where their uses are equivalent between English and Vietnamese. That is, noun makes up the biggest number of all $(44.81 \%$ in English and $46.18 \%$ in Vietnamese); adjective ranks second with $29.33 \%$ in English and $38.22 \%$ in Vietnamese; the following are verb and other types.

Another analogy is that, as mentioned at the beginning of this section, most of the love conceptual metaphors underlying English sensory perception terms are uncovered in Vietnamese. Maybe it is because of the universality of the conceptual metaphor. By using senses, human beings may perceive the world in a same way, which leads to the universal concepts [6]. Kövecses [17] also states there seems to be some 'universal bodily experience' (including sensory perception) that causes the same conceptual metaphors in diverse languages. Additionally, this is also true to the metaphor LOVE IS AN OBJECT, which is used the most widely in both English and Vietnamese poetry (see table 1 and 2). This metaphor's frequency amounts to 26.05 per cent in English and 19.50 per cent in Vietnamese. The result may also be shed light on by Szwedek's [30] proposition in which visual information is believed more attractive than other sensory one. Examing the metaphorical expressions of the OBJECT metaphor, we realize the visual perception terms make up the largest number of all (about $81.82 \%$ in English and $79.20 \%$ in Vietnamese).

Along with the common conception of love such as its visibility (see table 3 ), its touchableness (see table 4), its flavours (see table 5 and 6) or its sound (see table 7), the specific images of love are alike to both English and Vietnamese poets; for example, the beauty of love as in (1) and (4), the flower of love (see examples 7 and 9), the fire of love in (20) and (23) or even the pain of love as in (26) and (28). Moreover, there is also the emergence of surprisingly shared linguistic metaphors in these two languages. Looking back to example 4 again, we can learn about love beauty via 
the Vietnamese expression "ái tình đẹp" which is equivalent to beautiful love in English as in the following lines.

(43) I'd tell you how much cherish you, and our beautiful love. (Bobette Bryan)

Beside the expressions beautiful - đẹp, many other equivalent terms are found in English and Vietnamese poetry. They are light - ánh sáng, dark - u ám, glorious - rực rỡ, fair đẹp, pale - bạc phếch, see - thấy, seek - tìm, look - nhìn, heavy - nặng, light - nhẹ, cold - lạnh, freezing - giá, hot nóng, warm - âm, soft - mềm, touch - chạm, agony - nhức buốt, sweet - ngọt, bitter - đắng, sour - chua, fragrant - thơm, in brilliant colours - sắc màu rực rỡ and so on. These resemblances may be brought about by the universal experiences of human senses. They once again help confirm the 'universality of the conceptual organization of sensory perception in human brain' [12].

In sum, the sensory perception terms used to draw love are rather universal, particularly in English and Vietnamese poetry. The similarities are not only present in concepts, the way to metaphorically conceptualize love but also manifested in words. Evidently, a lot of metaphorical expressions of love in terms of sensory perception are detected the same in both the languages. However, these phenomena do not mean that all the linguistic sensory expressions are the same in expressing love. There still exist several differences between the two languages.

\subsubsection{Differences}

A potential universal conceptual metaphor does not lead to the same linguistic metaphors in different languages [2] by virtue of the distinct of embodied experiences which is supposed 'to play a role in conceptualizing the world' [7]. Therefore, in spite of a majority of the similar conceptual metaphors found in English and Vietnamese, the expressions of love are tolerably different. Let us start with the metaphor LOVE IS A LIVING ORGANISM which is discovered in both English and Vietnamese. Most of English linguistic metaphors of love are under visual perception expressions (namely eyes, find, look, look for, see, seeing, seek, spy) while they are almost auditory terms in Vietnamese (viz nghe, gọi, reo, tiếng, tiếng thi thầm, tiếng nấc). This phenomenon happens because of cultural differences between the Westerners and the Easterners.

The studies by Biesheuvel and Ombredance prove Western people are in more favour of visual stimuli [4]. Correspondingly, the Westerners often prefer treating vision to other senses. Moreover, the world of sight is an object world whereas the world of sound is an event world [22]. People in Western cultures are more independent; they usually focus on self, individual and central object [33]. It may consequently be easy to understand why English is prior to visual terms. By contrast, people in East Asian cultures are more interdependent. They often tend to monitor their environment and everything around [33]. This may answer the question of more audial terms in the Vietnamese conceptual metaphor above. This explanation also fits in our data statistics (see table 8) where the proportion of English visual perception expressions is more than that of Vietnamese ones; and the percentage of Vietnamese auditory perception terms is more than that of English ones.

In another case where love is translated as music, the expressions are dissimilar between the two languages; for example,

(44a) ... the halls of my heart are filled with moonlit sonatas (Jason Sterner)

(44b) Tình so chưa đủ ngũ âm

(Love hasn't had enough five tones yet) (Thanh Nguyên)

The cultural factors appear to be clearly displayed in these lines. In (44a), love is compared to sonatas, a genre of classical music that was generated in the Western culture. Meanwhile, the musical term in (44b) is absolutely Vietnamese with the expression $n g \tilde{u}$ âm (five tones) because 'Vietnamese music is pentatonic in scale' [20] including Hò, Xự, Xang, Xê, Cống. Besides, English musical terms employed to refer to love are the more common nouns such as song, sonata, melody and music while they are more specific in Vietnamese including ngũ $\hat{a} m$ (five tones), tiếng chuông gió (wind chimes) (see table 7). This difference may be clarified by the holistic and analytic features that characterize different cultures. It is known that the Asian culture is holistic while the Western one is analytic [33]. That is, the Asians (including the Vietnamese) usually pay more attention to the context of the object, the environment around it and its relationships whereas the Westerners' attention tends to focus on only individual object itself. As a result, the images described in Vietnamese are relatively clearer, more specific and in more details than those in English.

Returning to table 9, we can learn that verbs are used more in English while adjectives are more in Vietnamese. The quantity of English verbs makes up 22.95 per cent, approximately 1.7 times as many as that of Vietnamese. The number of Vietnamese adjectives accounts for 38.22 per cent while only 29.33 per cent goes into English ones. This may be a tolerably fascinating result but it is really hard to interpret. We think it is perhaps derived from the Westerners' dynamicity and Easterners' passivity, which may affect their thoughts and the language they use. According to Bagozzi et al [1], the Western people are often active and don't mind changes whereas the Eastern people (including the Vietnamese) are fairly passive and don't like changes. The verb is the most versatile word class, appearing in many guises. In consequences, the Westerners tend to use verbs more often than other classes and the Easterners do not.

Another dissimilarity is that there is a big gap in the quantity of gustatory perception terms between English and Vietnamese. In these languages, the number of expressions of taste ranks third. Nonetheless, these terms in English are nearly 4.5 per cent less than the second while this number is over 15 per cent in Vietnamese (see table 8). The numbers tell us that the Westerners seem to be more interested in tastes than the Easterners. Yet, conflicting to their frequency, English gustatory perception expressions applied to talk about love are poorer than those in Vietnamese. Looking at 
the table 5, we can see there are only mono-tastes in English while they are often complex in Vietnamese such as ngot lịm, ngọt ngào, ngọt bùi, ngọt dịu, đắng cay, mặn nồng.

Table 10. Frequency of tastes in English and Vietnamese metaphorical expressions of love.

\begin{tabular}{lllll}
\hline \multirow{2}{*}{ Tastes } & English & \multicolumn{3}{l}{ Vietnamese } \\
\cline { 2 - 5 } & Frequency & $\mathbf{\%}$ & Frequency & $\mathbf{\%}$ \\
\hline Sweetness & 47 & 92.16 & 9 & 34.62 \\
Bitterness & 3 & 5.88 & 9 & 34.62 \\
Sourness & 1 & 1.96 & 1 & 3.85 \\
Saltiness & 0 & 0 & 5 & 19.23 \\
Flavourlessness & 0 & 0 & 2 & 7.69 \\
\hline
\end{tabular}

Moreover, in English there are three tastes detected in our investigation, encompassing sweetness, bitterness and sourness while the number is five in Vietnamese data, comprising sweetness, bitterness, saltiness, sourness and flavourlessness. Perhaps this difference originates from the distinction between Western and Eastern traditional basic tastes. It is said the most basic tastes in Asian cultures are sweet, salty, sour, bitter and pungent; but in the West, there are only sweet and bitter [24]. Surprisingly, among the tastes uncovered, sweetness is dominant in English (accounting for 92.16 per cent) whereas bitterness shares the leading position with sweetness in Vietnamese (34.62 per cent for each) (see table 10). This phenomenon may be cast light on by the cultural effect on positive and negative emotion. According to Bagozzi et al. [1], Western people prefer to follow their dreams. Love in Western culture is the result of a person's private wishes and desires [32]. It will be destroyed if it does not meet the personal benefit of the ones in this relationship. Hence, when they are in love, the Westerners usually find more satisfaction than disappointment. In addition, love is inherently 'a wondrous state, deep, tender, and rewarding' [11]. People who are in love often feel happy, thus sweet. However, love, for Eastern people, is often interpreted in relationships between persons and their environment, so it tends not to depend on subjective feeling of the persons in this relationship [32]. Furthermore, Eastern people don't like changes [1]. In an unsatisfactory relationship, they tend to resign themselves to live with it instead of changing it, for instance,

(45) Tôi vẫn đi bên cạnh cuộc đời

Ái ân lạt lẽo của chồng tôi

(I'm still going beside my husband with his unflavoured love) (TTKH)

Obviously, the love relationship here is not as good as it is always expected in marriage; but it is kept alive. They live with it and suffer pains from it, thereby bitter. This may partly make the equality of the frequency of bitterness and sweetness in Vietnamese clearer.

The negative and positive emotions are not only perceived by taste but also identified by all senses. Similar to taste, the sensory expressions of negative feelings in English are less than those in Vietnamese. Our findings show there are 48 out of 549 expressions of this types in English (approximately 8.74 per cent) and 89 among 641 Vietnamese ones (occupying 13.88 per cent).
In summary, we have found out a variety of similarities and differences between English and Vietnamese sensory perception terms metaphorically used for love. The similarities occur by virtue of the universality of conceptual metaphors, the same way in perceiving the world through senses. The differences are suggested as a result of private habits, customs, and lifestyles in each particular culture.

\section{Conclusion}

Thanks to metaphor, love which is inherently an abstract domain becomes more concrete and tangible. It is diversified in terms of sensory perception consisting of vision, tactition, gustation, olfaction and audition. Its variety is manifested in both negative and positive aspects and mainly expressed by three main kinds of words (nouns, verbs and adjectives). Nouns account for the largest number in both English and Vietnamese. Verbs and adjectives respectively share the second and the third positions in English; but adjectives reach the second rank in Vietnamese.

As conceptual metaphor is universal, the conceptual metaphors of love underlying sensory metaphorical expressions are all similar between the two languages, with a total of fifteen source domains (namely OBJECT, NUTRIENT, CONTAINER, UNITY, JOURNEY, FIRE, LIVING ORGANISM, DISEASE, RAPTURE, OPPONENT, BLINDNESS, PLANT, MUSIC, LIFE and SUN/MOON/STARS). We also discover an emergence of the LOVE-AS-AN OBJECT metaphor as the top in both English and Vietnamese. If its quantity is overwhelming in comparison with the others, it is because of the fact that people appear to respond better to visual information which occupies a majority of expressions in this metaphor. The visual perception terms are found to constitute the biggest quantity in both the languages. The next is tactition, which is supposed as a result of a great yearning to attachment and closeness in love relationship.

Along with sight and touch, taste, smell and sound are also exploited much in expressing love in English and Vietnamese. However, Vietnamese gustatory and auditory terms look more subtle and complex than English ones. Besides, there are many other differences between these two languages. A great part of the dissimilarity comes from linguistic metaphors, which is predicted and expected. It is because 'metaphorical expressions have a basis in our physical and cultural experience' [19].

In conclusion, love can be conceptualized in both English and Vietnamese terms of sensory perception. Because of universal bodily experiences [17], the universality of shaping the world by senses [6] and the universality of conceptual metaphors [19], several resemblances between the two languages are uncovered in both conceptual and linguistic metaphors. However, language and culture exist and develop in mutual affecting. As a result, the translation of love in each different culture is certainly different, which is completely in accordance with the dissimilarities in using sensory perception terms for love between English and Vietnamese. 


\section{References}

[1] Bagozzi R. P, Wong N. and Yi Y., "The role of culture and gender in the relationship between positive and negative affect", Cognition and Emotion, 13 (6), 1999, pp. 641-672.

[2] Barcelona A., "On the plausibility of claiming a metonymic motivation for conceptual metaphor", Metaphor and Metonymy at the Crossroads, Berlin: Mouton de Gruyter, 2000, pp.31-58.

[3] Barth F. G et al., Sensory Perception: Mind and Matter, Spring Wien, New York, 2012.

[4] Berry J. W. et al., Cross-cultural Psychology: Research and Applications, $2^{\text {nd }}$ Edition, Cambridge University Press, 2002.

[5] Bucker J., Ayurvedic Balancing: An Integration of Western Fitness wit Eastern Wellness, Llewellyn Publications, USA, 2002.

[6] Callies M. and Zimmermann R., Cross-culture metaphors: Investigating Domain Mappings Across Cultures, PhilippsUniversität Marburg, 2002.

[7] Feldman J. A., From Molecule to Metaphor: A Neural Theory of Language, the MIT Press, 2006.

[8] Fell L., Mind and Love: The human experience, Biosong, 2010.

[9] Feng Y. and Lapata M., "Visual information in semantic representation", Human Language Technologies: The 2010 Annual Conference of the North American Chapter of the $A C L, 2010$, pp. 91-99.

[10] Gibbs R., "Taking metaphor out of our heads and into the cultural world", in Metaphor and cognitive linguistics, Amsterdam: John Benjamins, 1999, pp.145-166.

[11] Harlow H. F., "The Nature of Love", American Psychologist, 13, 1958, pp. 673-685.

[12] Hillis A. E., The Handbook of Adult Languages Disorders, Psychology Press, New York, 2002.

[13] Kövecses Z., Emotion Concepts, New York - Berlin: Springer-Verlag, 1990.

[14] Kövecses Z., Metaphor and Emotion: Language, Culture, and body in human feeling, Cambridge: Cambridge University Press, 2000.

[15] Kövecses Z., Metaphor in Culture: Universality and Variation, Cambridge and New York: Cambridge University Press, 2005.

[16] Kövecses Z., Metaphor: A Practical Introduction, $2^{\text {nd }}$ Edition, Oxford: Osford University Press, 2010.
[17] Kövecses Z., "Metaphor and Culture", Acta Universitatis Sapientiae, Philologica, 2(2), 2010, pp. 197-220.

[18] Lakoff G., The Contemporary Theory of Metaphor, Second Edition, Cambridge: Cambridge University Press, 1993.

[19] Lakoff G. and Johnson M., Metaphors We Live By, The University of Chicago Press, Chicago and London, 1980.

[20] McLeod M. W. and Nguyen Thi Dieu, Culture and Custom of Vietnam, Greenwood Press, London, 2001.

[21] Merriam-Webster Collegiate Dictionary, 11 $1^{\text {th }}$ Edition, An Encyclopedia Britannica Company, 2000.

[22] Ong W. J., "World as view and world as event", in Environmental: Essays on the Planet as Home, Shepard and McKinley (eds), New York: Houghton, 1971, pp. 61-79.

[23] Ortiz-Millán G., "Love and rationality: On some possible rational effects of love", Kriterion, 48 (115), 2007, pp. 127144.

[24] Polansky R., Aristotle's De anima, Cambridge: Cambridge University Press, 2007.

[25] Pragglejaz Group, "MIP: A Method for Identifying Metaphorically used Words in Discourse", Metaphor and Symbol, 22(1), 2007, pp. 1-39.

[26] Rodaway P., Sensuous Geography: Body, Sense, and Place, London: Routledge, 1994.

[27] Schäfer G., "Romantic Love in Heterosexual Relationships: Women's Experiences", Journal of Social Sciences, 16(3), 2008, pp. 187-197.

[28] Sternberg R. J., "A Triangular Theory of Love", Psychology Review, 93, 1986, pp. 119-135.

[29] Stevens Q., The Ludic City: Exploring the Potential of Public Spaces, London and New York: Routledge, 2007.

[30] Szwedek A., "Sense, perception and metaphors (of object and objectfication)", Multis vocibus de lingua, 2000, pp. 143 153.

[31] Tessari H., Metaphors we love by: on the cognitive metaphors of love from the $15^{\text {th }}$ century to the present, Adam Mickiewicz University Press, 2001.

[32] Valsiner J., The Oxford Handbook of Culture and Psychology, Oxford University Press, New York, 2012.

[33] Warnum M. E. Wet al., "The origin of cultural differences in Cognition: Evidence for the Social Orientation Hypothesis", Curr Dir Psychol Sci., 19(1), 2010, pp. 9-13.

[34] http://changingminds.org/techniques/language/persuasive/sens ory_language.htm.

[35] Woodman, http://www.goodreads.com/quotes/283685. 